\title{
CAN THE SECTIONAL POSITION OF GENTIANA CACHEMIRICA BE CLARIFIED BY A DETAILED ANALYSIS OF ITS MORPHOLOGY?
}

\author{
N. Davitashvili \& G. Karrer
}

\begin{abstract}
Gentiana cachemirica is a rare plant from northern Pakistan and northwestern India. The sectional position of this species has been a matter of considerable debate. Various authors have placed Gentiana cachemirica in one of three different sections - Gentiana sect. Isomeria, Gentiana sect. Kudoa or Gentiana sect. Pneumonanthe. The present paper assesses the taxonomic affinities of this species using a detailed study of its morphology accompanied by morphological phylogenetic and cluster analyses. Characters of the seed testa, corolla morphology and growth architecture were studied for selected species from the above-mentioned sections and closely related Gentiana sect. Cruciata. Representatives of Gentiana sect. Ciminalis were used as outgroups. Our results suggest that

G. cachemirica belongs to Gentiana sect. Pneumonanthe and that its affinities are closer to the Western Asiatic group of this section.
\end{abstract}

Keywords. Gentiana cachemirica, Gentiana septemfida, growth architecture, Isomeria, Kudoa, Pakistan, Pneumonanthe, western Asia.

\section{INTRODUCTION}

Gentiana cachemirica Decne. is a rare plant from northwestern Pakistan and northwestern India. It occupies moist rocky ledges in the eastern Hindu Kush range and westernmost Himalayas (Polunin \& Stainton, 1990; Omer \& Qaiser, 1995b). This species was discovered by Decaisne. Hooker was not aware of Decaisne's publication and described the same species under the name Gentiana loderi Hook.f. Later, Clarke (1885) considered the markedly different Gentiana stipitata Edgew. to be conspecific with $G$. cachemirica. After almost 100 years of confusion Smith (1961) separated Gentiana stipitata from $G$. cachemirica and recognized $G$. loderi as a synonym of the latter.

In general, Gentiana cachemirica is poorly known because it has been rarely collected. This may partially account for the various conflicting sectional treatments of this species (see Table 1). Clarke (1885) included Gentiana cachemirica in Gentiana sect. Pneumonanthe (Gled.) Gaudin. According to his classification Gentiana sect. Pneumonanthe comprised plants 'with one or more flowers and wingless seeds'. On the basis of flower and seed morphology Kusnezow (1894) split 'Pneumonanthe' s.1. into three sections: Gentiana sect. Frigidae Kusn., Gentiana sect. Isomeria Kusn. and Gentiana sect. Pneumonanthe s.str. Gentiana cachemirica (including G. stipitata) was 
TA B LE 1. Sectional treatment of Gentiana cachemirica by different authors. Sections in which Gentiana cachemirica was placed in bold; n.ac., not accepted

\begin{tabular}{llll}
\hline \hline Clarke (1885) & Kusnezow (1894) & Smith (1961) & Ho \& Liu (2001) \\
\hline Pneumonanthe & Pneumonanthe & Pneumonanthe & Pneumonanthe \\
n.ac. & Frigidae & Frigidae & Frigidae \\
n.ac. & n.ac. & n.ac. & Microsperma \\
n.ac. & n.ac. & n.ac. & Monopodiae \\
n.ac. & n.ac. & n.ac. & Phyllocalyx \\
n.ac. & n.ac. & n.ac. & Kudoa \\
n.ac. & Isomeria & n.ac. & Isomeria \\
\hline \hline
\end{tabular}

placed within his newly established section Isomeria comprising four further taxa: Gentiana amoena Clarke, G. delavayi Franch., G. depressa Don and G. loderi. This section unified Himalayan and southwestern Chinese taxa with 'indistinct corolla lobes and large symmetrical plicae' (Kusnezow, 1894). Smith (1961) showed that the differentiating characters of Kusnezow's Gentiana sect. Isomeria such as symmetrical plicae and indistinct corolla lobes also occur in other Himalayan gentians besides Gentiana sect. Isomeria. As a consequence, he rejected this section and placed Gentiana amoena, G. delavayi and G. depressa in Gentiana sect. Frigidae. Furthermore, he separated Gentiana stipitata from G. cachemirica, regarding the first species to be a member of Gentiana sect. Frigidae. In Smith's opinion, Gentiana cachemirica (including G. loderi) had affinities with eastern populations of G. septemfida Pall. and should be included in Gentiana sect. Pneumonanthe. Smith (1961) describes well the morphological peculiarities of Gentiana stipitata and other members of Gentiana sect. Frigidae but the paper lacks comparable information for G. cachemirica and, therefore, does not support the inclusion of this species in Gentiana sect. Pneumonanthe on the basis of morphology. Smith's classification of Gentiana cachemirica was accepted by Schiman-Czeika (1967) and Halda (1996). The recent monographers Ho \& Liu $(1990,2001)$ ascribed much weight to growth architecture and seed morphology for the sectional classification of Gentiana and recognized 15 sections. In their study the representatives of Gentiana sect. Pneumonanthe are characterized by 'sympodial growth form', whereas G. cachemirica is a monopodial, rosulate plant. Therefore, they ignored the classification by Smith (1961) and placed Gentiana cachemirica in Gentiana sect. Kudoa (Masam.) Satake \& Toyok. ex Toyok. This section was separated from Gentiana sect. Frigidae based on the 'monopodial branching pattern of the shoot, presence of an apical rosette, honeycomb-like seed testa structure, symmetrical plicae, and a single terminal flower' (cf. Table 2).

The conflicting ideas about the sectional position of Gentiana cachemirica illustrate that its morphology is not yet fully understood. As a result, the sectional placement of this species still remains unclear. A large number of molecular and morphological studies dealing with various aspects of the family Gentianaceae have been carried out during the last few years (e.g. Struwe \& Albert, 2002; Hagen \& Kadereit, 2003; 
T A B LE 2. Comparative morphology of Gentiana cachemirica and Gentiana sections Isomeria, Kudoa and Pneumonanthe, according to Ho \& Liu (2001); ?, not documented or mentioned

\begin{tabular}{|c|c|c|c|}
\hline Kudoa & Isomeria & Pneumonanthe & Gentiana cachemirica \\
\hline $\begin{array}{l}\text { Seed testa with } \\
\text { hexagonal pits }\end{array}$ & $\begin{array}{l}\text { Seed testa with simple } \\
\text { and spongy complex } \\
\text { hexagonal pits }\end{array}$ & $\begin{array}{l}\text { Seed testa } \\
\quad \text { reticulate }\end{array}$ & $\begin{array}{l}\text { Seed testa with } \\
\text { hexagonal pits }\end{array}$ \\
\hline Seed without wing & $\begin{array}{l}\text { Seeds without wings } \\
\text { or membranous } \\
\text { lamellae }\end{array}$ & $\begin{array}{l}\text { Seeds with } \\
\text { various wings }\end{array}$ & Seed without wing \\
\hline $\begin{array}{c}\text { Plants branching } \\
\text { monopodially }\end{array}$ & $\begin{array}{l}\text { Plants branching } \\
\text { sympodially }\end{array}$ & $\begin{array}{l}\text { Plants branching } \\
\text { sympodially }\end{array}$ & $\begin{array}{l}\text { Plant branching } \\
\text { monopodially }\end{array}$ \\
\hline $\begin{array}{l}\text { Corolla plicae } \\
\text { always } \\
\text { symmetrical }\end{array}$ & $\begin{array}{l}\text { Corolla plicae } \\
\text { symmetrical } \\
\text { and asymmetrical }\end{array}$ & $?$ & $\begin{array}{l}\text { Corolla plicae always } \\
\text { symmetrical }\end{array}$ \\
\hline Taproot present & Taproot absent & Taproot present & Taproot present \\
\hline Stolons absent & Stolons present & Stolons absent & Stolons absent \\
\hline
\end{tabular}

Greimler et al., 2004; Chen et al., 2005; Jang et al., 2005; Yuan et al., 2005), but the species considered for the present study have not been considered for any analysis. In the present paper we aim to elucidate various aspects of the morphology of Gentiana cachemirica and clarify the sectional position of this species.

We compare morphological features of Gentiana cachemirica and species that represent sections in which $G$. cachemirica was placed, and use cluster analysis to re-evaluate the sectional position of $G$. cachemirica. In addition, we discuss modern distribution ranges and climatic preferences of members of the sections under study.

\section{MAterials AND Methods \\ Selection of taxa analysed}

Representatives of all three sections Isomeria, Kudoa and Pneumonanthe (excluding G. asclepiadea L.; see e.g. Löve \& Löve, 1972; Mészáros, 1994; Yuan et al., 1996; Karrer, 1997; Davitashvili \& Karrer, 2003), in which Gentiana cachemirica was placed by various authors, were included in our morphological phylogenetic and cluster analyses. From Gentiana sect. Pneumonanthe taxa from Euro-Siberian, Eastern Asian and North American groups were selected (Kusnezow, 1894). In the case of Gentiana sect. Isomeria, sensu Ho \& Liu (2001), we analysed most species of Gentiana ser. Confertifoliae Marquand, since its species composition corresponds to Gentiana sect. Isomeria sensu Kusnezow (1894). From Gentiana sect. Kudoa most taxa of Gentiana ser. Monanthae (Harry Sm.) T.N.Ho, and additionally one species from Gentiana ser. Ornathae Marquand, were selected. In addition, Gentiana cruciata L. and G. olivieri Griseb. (Gentiana sect. Cruciata Gaudin) were included in our analysis. This was done because representatives of Gentiana sect. Cruciata show 
TABLE 3. List of species analysed and their position within the respective sections. Infrasectional groupings of Gentiana sections Kudoa and Isomeria according to Ho \& Liu (2001), and of Gentiana sect. Pneumonanthe after Kusnezow (1894)

\begin{tabular}{lll}
\hline \hline Section & Subsectional grouping & Species \\
\hline Isomeria & Confertifoliae & $\begin{array}{l}\text { G. depressa } \\
\text { Kudoarnula }\end{array}$ \\
& Monanthae & G. cachemirica \\
& & G. stipitata \\
Pneumonanthe & Grnatae szechenyii \\
& Western Asia & G. veitchiorum \\
& Euro-Siberia & G. gelida \\
& Eastern Asia & G. pneumonanthe \\
& Western Asia & G. scabra \\
& North American & G. septemfida \\
Cruciata & G. andrewsii \\
Ciminalis & G. sceptrum \\
& & G. cruciata \\
\hline \hline
\end{tabular}

morphological similarities to G. cachemirica, and, according to previous molecular studies, have close affinities to Gentiana sect. Pneumonanthe (Yuan et al., 1996). Other Asian sections - Gentiana sect. Chondrophyllae Bunge and Gentiana sect. Monopodiae (Harry Sm.) T.N.Ho - having close phylogenetic relationships to Gentiana sect. Isomeria, Gentiana sect. Kudoa and Gentiana sect. Pneumonanthe (Yuan et al., 1996), as well as Gentiana sect. Otophora Kusn., were not included in the analysis as they lack morphological affinities to the species of our interest. Gentiana acaulis L. and G. clusii E.P.Perrier \& Songeon from European Gentiana sect. Ciminalis (Adans.) Dumort. were selected as outgroups, since Gentiana sect. Ciminalis is sister to sections included in the analysis (Yuan et al., 1996). The taxonomic position of the taxa within sectional frameworks proposed so far by different authors is presented in Table 3.

\section{Plant material}

All selected taxa were studied at the herbaria of Kew (K), Edinburgh (E), Vienna (W), and Tbilisi (TBI, TB), or were examined using living specimens from field collections. A list of selected voucher specimens examined is presented in Appendix 1.

Seeds of Gentiana depressa, G. pneumonanthe, G. scabra Bunge, G. septemfida and G. urnula Harry Sm. were collected from mature capsules of living plants or herbarium specimens. Seeds were put on stubs for SEM investigation. The stubs were spatter-coated with gold and examined using a scanning electron microscope (Philips XL30 ESEM). Information about seed shape and testa ornamentation of 
Gentiana cachemirica and G. stipitata was taken from Omer \& Qaiser (1995a) and Smith (1961), respectively.

Calyx and corolla drawings of Gentiana cachemirica, G. pneumonanthe, G. septemfida, G. szechenyii Kanitz and G. veitchiorum Hemsl. were made from prepared flowers.

All the other morphological characters were determined by the examination of macro- and micromorphological features of living and herbarium specimens.

\section{Selection of characters for cluster analysis}

Our criteria for character selection were independence of characters and stability or a high level of conservatism of character states within the species (Stuessy, 1990). We placed special emphasis on qualitative characters that were reported to have taxonomic importance (Ho \& Liu, 1990, 2001):

Shoot architecture. Gentians have various growth forms that are stable within the sections. This character complex has been used by many authors for sectional delimitation in the genus Gentiana (Smith, 1961; Karrer, 1997; Ho \& Liu, 1990, 2001; Renobales et al., 1999; Davitashvili \& Karrer, unpubl. data). The sections were differentiated by the type of growth form, the orientation of the belowground growth structures, the presence/absence of stolons, the branching intensity, etc.

Leaf system. Most gentians bear opposite cauline leaves, and develop rosettes. The leaves vary in the shape of the blade and in size. The rosettes vary in the presence/ absence of green leaves.

Seed micromorphology. Seed morphology is one of the main characters that has been used for the sectional classification of Gentiana (Kusnezow, 1894; Yuan, 1993; Ho \& Liu, 1990, 2001; Halda, 1996; Bouman et al., 2002; Davitashvili \& Karrer, unpubl. data). Seeds vary in testa cell shape, the presence/absence of wings and other characters (Bouman et al., 2002; Davitashvili \& Karrer, unpubl. data).

Flower morphology. The shape of the corolla is frequently used as a character for species delimitation but in some cases is also a very useful character for sectional classification (e.g. Gentiana sect. Calathianae Froel.). Similarly, variation in the margins of the plicae is traditionally used as a differential character within Gentiana.

Flower arrangement. Generally, gentian flowers are arranged in cymose inflorescences, but in some taxa and in some sections, for example Gentiana sect. Kudoa, the number of flowers in inflorescences is reduced to one.

Selected characters were coded as multistate characters (see Table 4).

\section{Analysis of morphological data}

The phylogenetic analysis was performed with PAUP 4.0b4a (Swofford, 1998). We conducted a maximum parsimony analysis, using a branch and bound search 
TABLE 4. Morphological characters of Gentiana cachemirica and possible relatives coded in multistate way

\begin{tabular}{|c|c|c|c|c|}
\hline$\overline{\text { No. }}$ & Characters & & & \\
\hline 1 & Plants branching sympodially (0) (Fig. 1B) & monopodially (1) (Fig. 1A,C-F) & & \\
\hline 2 & Main axis orthotropic $(0)($ Fig. $1 \mathrm{~A}, \mathrm{C})$ & plagiotropic (1) (Fig. 1B,D-F) & & \\
\hline 3 & Plants with stolons (0) (Fig. 1B) & without stolons (1) (Fig. 1A,C-F) & & \\
\hline 4 & Adult plant with primary root $(0)($ Fig. $1 \mathrm{~A})$ & without primary root (1) & & \\
\hline 5 & Apical rosette with scaly leaves (0) (Fig. 1C) & with green leaves (1) (Fig. 1A-B,D-F) & & \\
\hline 6 & Leaves ovate $(0)$ & lanceolate (1) & spathulate (2) & \\
\hline 7 & Testa cells isodiametric $(0)($ Fig. $2 \mathrm{~B}, \mathrm{H})$ & oblong (1) (Fig. 2D,F) & & \\
\hline 8 & $\begin{array}{l}\text { Testa cells form honeycomb-like pits }(0) \\
(\text { Fig. } 2 \mathrm{~A}-\mathrm{B}, \mathrm{G}-\mathrm{H})\end{array}$ & do not form (1) (Fig. 2C-F) & & \\
\hline 9 & Seeds with ribs $(0)$ & without (1) & & \\
\hline 10 & Micropylar end forms collar $(0)$ & does not form (1) & & \\
\hline 11 & Seeds compressed $(0)$ & not compressed (1) & & \\
\hline 12 & Testa cell walls are thickened $(0)$ & not thickened (1) & & \\
\hline 13 & Seed without wing $(0)$ & with extended chalazal end (1) (Fig. 2C) & with side wing (2) (Fig. 2E) & with wing $(3)^{*}$ \\
\hline 14 & $\begin{array}{l}\text { Corolla broad funnelform to campanulate } \\
\text { (0) (Fig. 1B,D-F) }\end{array}$ & narrow funnelform (1) (Fig. 1A) & urceolate (2) & bottle-like (3) \\
\hline 15 & Corolla plicae symmetrical (0) (Fig. 3A,D-F) & oblique (1) (Fig. 3B-C) & & \\
\hline 16 & Corolla plicae entire (0) (Fig. 3E,F) & toothed (1) (Fig. 3B-C) & fimbriate (2) (Fig. 3A,D) & \\
\hline 17 & Flowering shoot with only one flower $(0)$ & with cymes (1) & & \\
\hline
\end{tabular}

*Fig. 1 in Davitashvili \& Karrer (2006). 

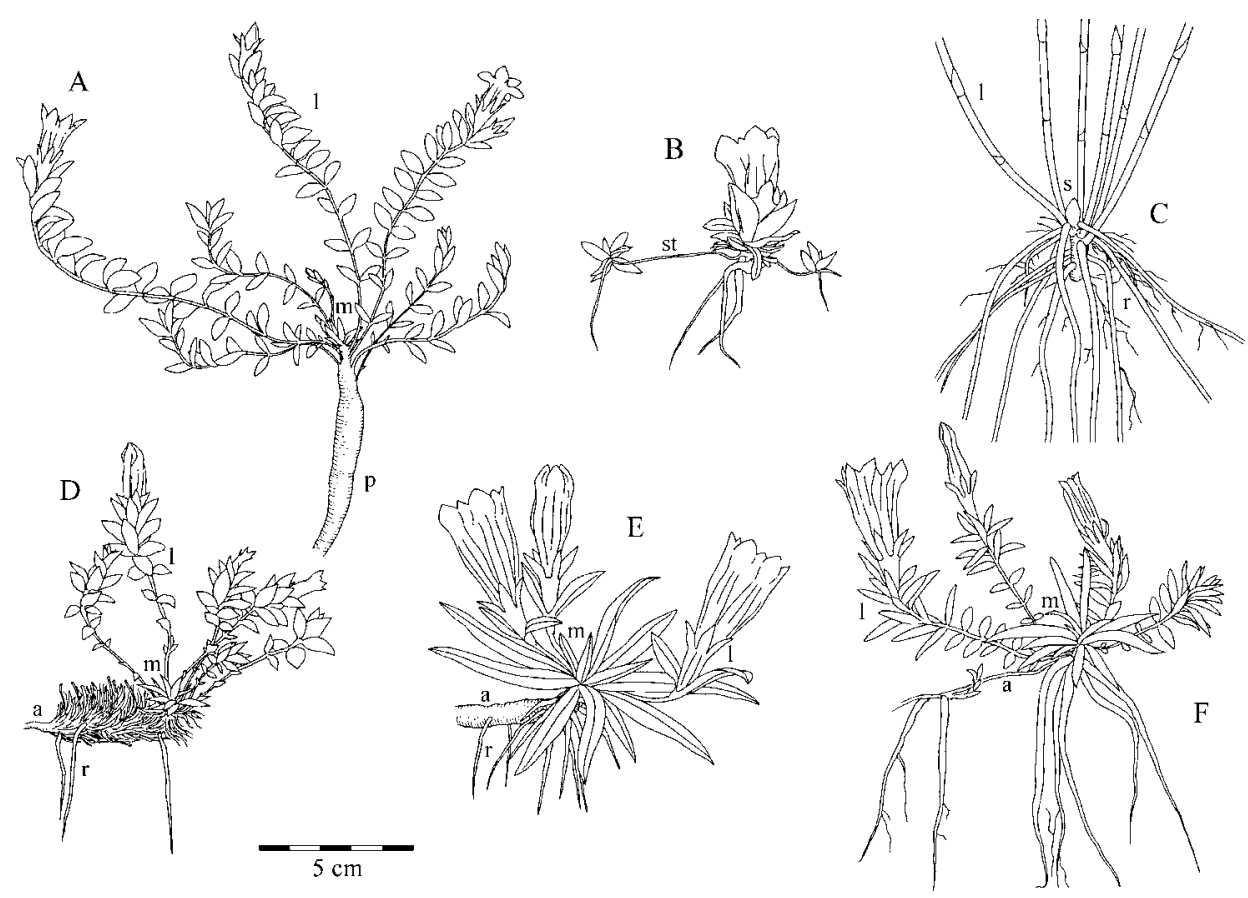

Fig. 1. Growth forms. A, Gentiana cachemirica. B, G. depressa. C, G. scabra. D, G. stipitata. E, G. szechenyii. F, G. veitchiorum. a, main axis; 1, lateral short-lived flowering stem; $\mathrm{m}$, monopodial rosette; $\mathrm{p}$, primary root; $\mathrm{r}$, adventitious root; $\mathrm{s}$, monopodial rosette of scale leaves; st, stolon.

algorithm as implemented in PAUP 4.0b4a (Swofford, 1998). All characters were treated as 'unordered' and had equal weight (Fitch parsimony; Fitch, 1971). Multistate taxa were interpreted as polymorphisms. Bootstrap values were obtained based on 1000 replications. Accelerated transformation (ACCTRAN) was used for character state optimization. The character state changes were determined using the 'trace all characters' option in MacClade version 3.01 (Maddison \& Maddison, 1992). For comparison, the analysis was also performed with the PAUP* 4.0b4a program using the neighbour-joining (NJ) clustering method, measuring a mean character difference as a distance measure with ties broken randomly and NJ bootstrap of 1000 replicates. The character states were recorded into a multistate matrix of 17 characters. The character matrix is presented in Appendix 2.

\section{RESULTS}

\section{Morphology of Gentiana cachemirica}

Gentiana cachemirica is clearly a perennial species. All herbarium specimens examined lacked the primary root, except one. The main axis is 5-7 mm thick. 

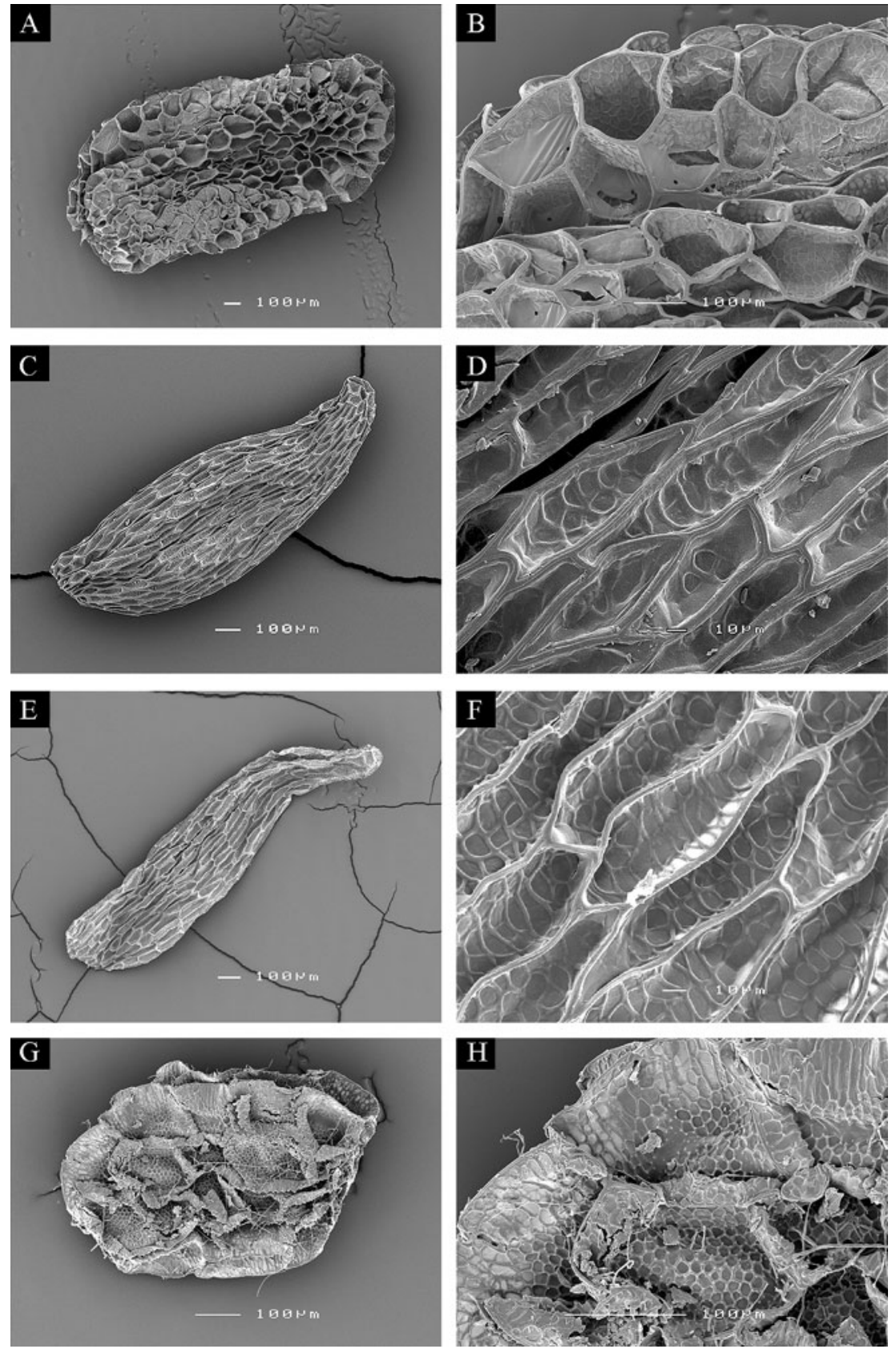

FIG. 2. Seeds and testa details of selected gentians representing the variation of characters within the compared taxa. A-B, Gentiana depressa (Dickoré (N-)812, private collection). C-D, G. pneumonanthe (Davitashvili 00-01, TBI). E-F, G. scabra (T. Koyana 833, W). G-H, G. urnula (Dickoré 6449, private collection). 
It grows monopodially, due to the activity of the apical meristem, which seems to be maintained throughout the life of the plant. The withered parts of the old flowering stems, dormant buds, and adventitious roots are attached to the belowground main stem. The apical buds are covered by scale leaves, which in turn are covered by the bases of the green, oblong-lanceolate, petiolate foliage leaves that form a small, poorly developed, rosette. The flowering stems only develop from lateral buds in the leaf axils of the primary stem. They bear ovate, 3-5-veined leaves, the lowermost scale-like and the largest occurring halfway up the flowering stem. The flowers are arranged in terminal cymes, although occasionally a solitary flower may occur as well.

The seeds of Gentiana cachemirica are elliptic in outline, with the chalazal end extended to form a wing; the testa cells are oblong (Omer \& Qaiser, 1995a).

The corolla of this species is narrowly funnelform, with distinct corolla lobes and symmetrical plicae with fimbriate margins (Fig. 3).

\section{Phylogenetic analysis of morphological characters}

All selected characters were informative for the parsimony analysis. The phylogenetic analysis of morphological characters yielded 29 best trees of 29 steps (consistency index $\mathrm{CI}=0.8621$, retention index $\mathrm{RI}=0.9322$, homoplasy index $\mathrm{HI}=0.2069$ and rescaled consistency index $\mathrm{RC}=0.8036)$. One of the best trees is presented in Fig. 4A.

Gentiana cachemirica does not group with other taxa of Gentiana sect. Kudoa or Gentiana sect. Isomeria, but is arranged within Gentiana sect. Pneumonanthe and thus makes this section paraphyletic. Together with Western Asian Gentiana septemfida, G. cachemirica forms a group (bootstrap value 66\%) that is characterized by the presence of ovate leaves and fimbriate plicae.

\section{Cluster analysis of morphological characters}

The result of the cluster analysis is presented in Fig. 4B. Gentiana cachemirica does not group together with other taxa of Gentiana sect. Kudoa or Gentiana sect. Isomeria, but is clustered (bootstrap value 74\%) with Gentiana septemfida, the Western Asian member of Gentiana sect. Pneumonanthe.

\section{DISCUSSION}

The sectional position of Gentiana cachemirica has been the subject of considerable controversy. Different authors have placed the species in three different sections: Gentiana sect. Isomeria, Gentiana sect. Kudoa and Gentiana sect. Pneumonanthe. Our morphological cluster analysis contradicts the treatment of Kusnezow (1894), who included Gentiana cachemirica within Gentiana sect. Isomeria. This section unifies plants with sympodial branching, belowground stolons (characters 1, 3 in Fig. 4A) 

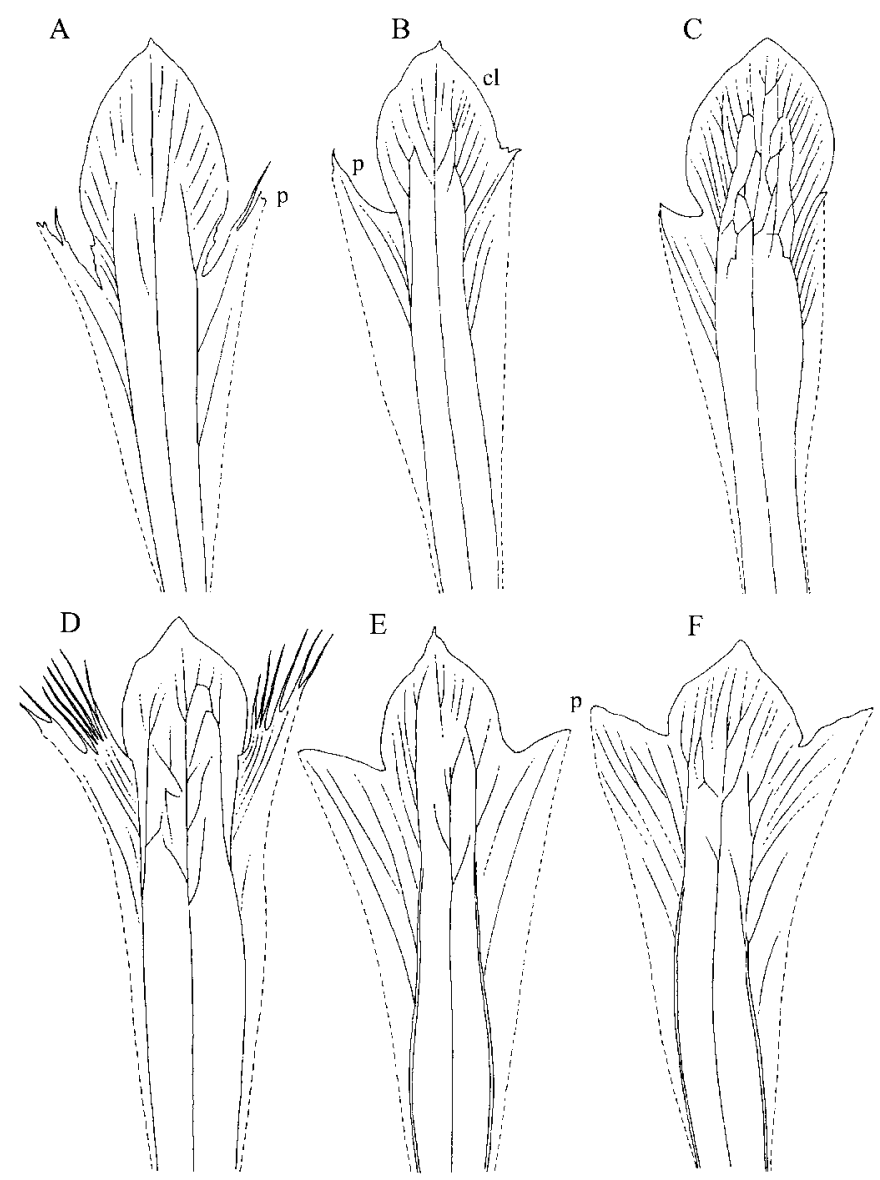

FIG. 3. Drawings of one corolla lobe with its adjacent plicae for selected gentians representing the variation of characters within the compared taxa. A, Gentiana cachemirica (B. L. Burtt \& M.A. Kazmi 1244, E). B, G. pneumonanthe (Davitashvili 00-01, TBI). C, G. scabra (T. Koyana 833, W). D, G. septemfida (Davitashvili 01-01, TBI). E, G. szechenyii (ChungtienLijiang-Dali Expedition CLD-90 No. 757, K). F, G. veitchiorum (F. Kingdon Ward 6171, K). p, plicae; cl, corolla lobe.

and honeycomb-like seed testas, a combination of characters that differ substantially from those of Gentiana cachemirica.

Based on its monopodial branching Ho \& Liu (2001) placed Gentiana cachemirica in Gentiana sect. Kudoa. Our examination shows that the branching mode of Gentiana cachemirica, as in Gentiana sect. Kudoa, is monopodial, but G. cachemirica develops an orthotropic persistent belowground shoot (character 2 in Fig. 4A), whereas representatives of Gentiana sect. Kudoa have exclusively plagiotropic belowground persistent shoots. This morphological peculiarity reflects differences in the synecology and growth architecture of Gentiana cachemirica as compared with 
A

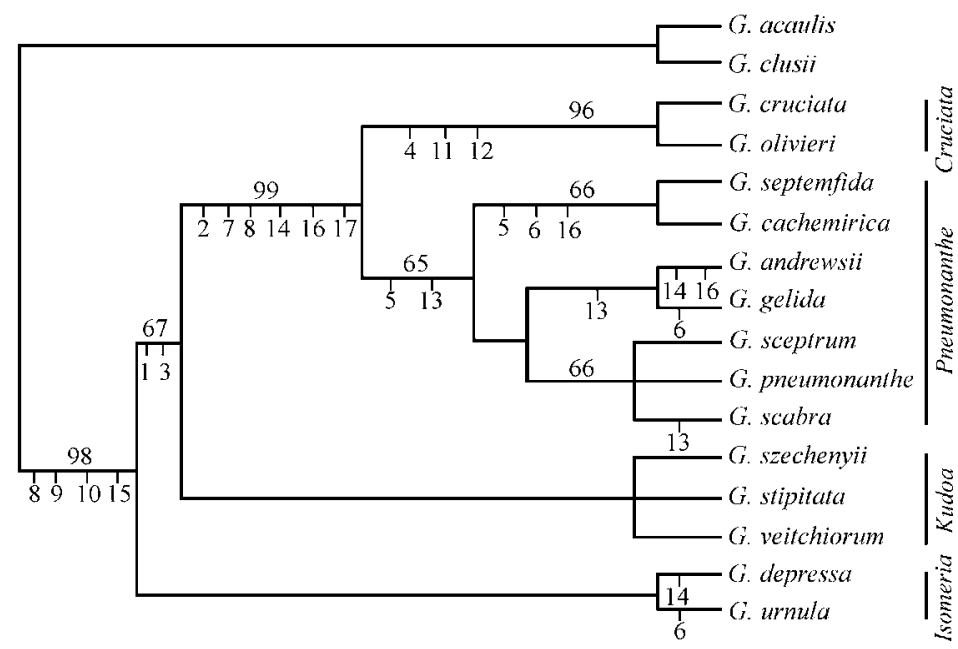

$\mathrm{B}$

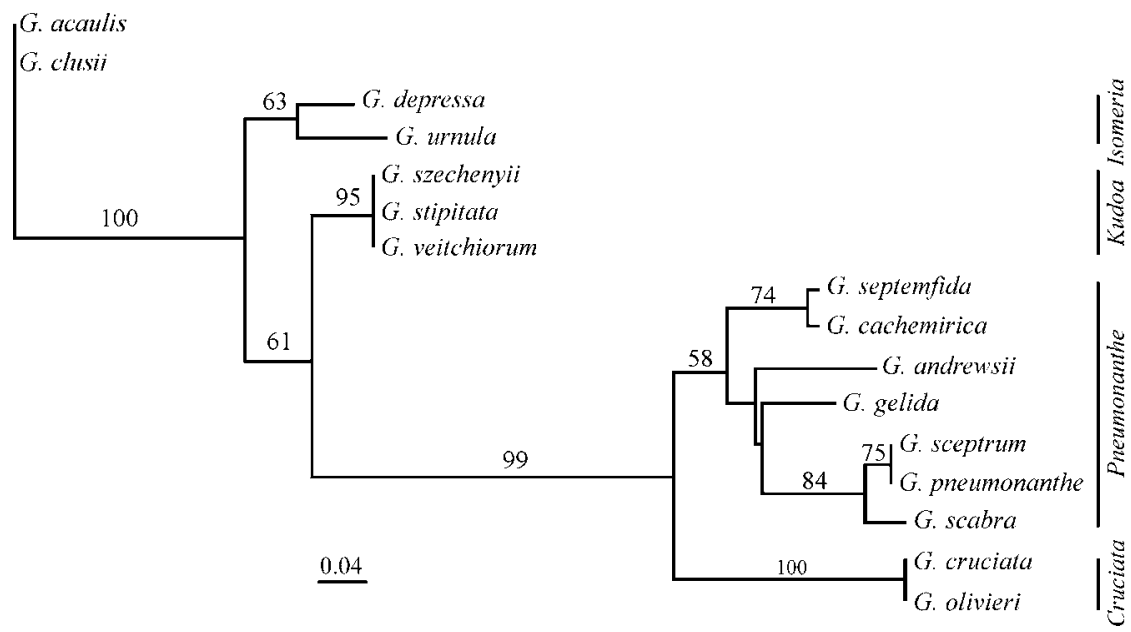

FIG. 4. Dendrograms obtained from the morphological phylogenetic and cluster analyses of Gentiana sections Ciminalis, Cruciata, Isomeria, Kudoa and Pneumonanthe. A, Parsimony analysis. B, Neighbour-joining analysis. Numbers above branches indicate bootstrap values. Numbers below branches indicate characters. The sectional affiliation is marked by vertical lines to the right of the species names following Ho \& Liu (2001).

other representatives of Gentiana sect. Kudoa. The horizontal main axis of most species in Gentiana sect. Kudoa elongates during the flowering period allowing for spatial expansion, while the orthotropic belowground stem in G. cachemirica restricts the plant to the same microhabitats. Thus different strategies are noticeable with respect to clonal reproduction of Gentiana cachemirica and the other species of Gentiana sect. Kudoa. The former develops, at the most, a few daughter branches, 
whereas the taxa of Gentiana sect. Kudoa tend to reproduce clonally and to develop expanded clumps. Ho \& Liu (2001) reported the taproot to be one of the characters of Gentiana sect. Kudoa. The primary root was found in Gentiana cachemirica, whereas all other representatives of Gentiana sect. Kudoa lacked the taproot. In all studied specimens the horizontal axis bore only contractile roots, whereas older parts of the horizontal main axis had died out (Fig. 1). Taking into consideration the growing strategy of taxa from this section (see description above) the statement on the presence of a primary root in Gentiana sect. Kudoa (Ho \& Liu, 2001) would seem to be a misinterpretation.

Seed micromorphology (characters 7, 8 in Fig. 4A) does not support the inclusion of Gentiana cachemirica within Gentiana sect. Kudoa either. Omer \& Qaiser (1995a) showed that Gentiana cachemirica has seeds with elongated testa cells and extended chalazal ends, whereas the seeds of the other taxa in Gentiana sect. Kudoa are wingless with honeycomb-like testa cells (Smith, 1961; Yuan, 1993; Bouman et al., 2002; Davitashvili \& Karrer, unpubl. data).

The flowering shoots of representatives of Gentiana sect. Kudoa always terminate in solitary campanulate flowers with entire plicae and produce shortened upper internodes with overlapping elliptic to linear leaves (characters 6, 14, 16, 17 in Fig. 4A). Sometimes the lower leaves wither and fall off so that only the lower internodes and upper leaves remain. In Gentiana cachemirica the flowering stem produces evenly distributed internodes with ovate leaves and solitary or sub-solitary narrowly funnelform flowers with fimbriate plicae.

The presence of a monopodial orthotropic main axis, the primary root (character 4 in Appendix 2), oblong seed testa cells, and a narrowly funnelform corolla, arranged in a multiflower inflorescence, makes Gentiana cachemirica similar to members of Gentiana sect. Cruciata. However, differences in seed micromorphology, namely the absence of thickened testa cell walls and compressed seeds (characters 11, 12 in Fig. 4A), do not affirm the inclusion of this species in Gentiana sect. Cruciata. The primary root was documented in only one specimen of Gentiana cachemirica. It appears that the taproot and older parts of the belowground stem die as the plant ages, though this may be an artefact of incomplete specimen sampling. Therefore further sampling is necessary to understand the development of this character in this species.

Close affinities between Gentiana cachemirica and the representatives of Gentiana sect. Pneumonanthe were suggested, but without clear evidence, by Smith (1961), Schiman-Czeika (1967) and Halda (1996). Our morphological phylogenetic and cluster analyses confirm the suggestions of the above-mentioned authors. Therefore, it seems reasonable to exclude Gentiana cachemirica from Gentiana sect. Kudoa and place this species within Gentiana sect. Pneumonanthe.

Gentiana cachemirica shares with the representatives of Gentiana sect. Pneumonanthe seeds with an extended chalazal end, but differs by the presence of a rosette with small green foliage leaves (characters 5, 13 in Fig. 4A). Most species of Gentiana sect. Pneumonanthe lack green rosette leaves, developing only transparent scale 
leaves on the main axis. Thus Serebryakova (1979) defined the growth mode of the section as 'non-rosulate' monopodial. However, some species seem to provide exceptions to this definition. A green-foliaged rosette is documented for a few individuals of Gentiana septemfida from the Dsungarian Alatau (Serebryakova, 1979) and for seedlings and juveniles in populations of G. septemfida from the Caucasus (unpubl. data). The North American taxon Gentiana newberryi A.Gray (Gentiana sect. Pneumonanthe) also bears green rosette leaves but, in contrast to G. cachemirica, its leaves are large and well developed. Morphologically this species is quite distinct from other representatives of Gentiana sect. Pneumonanthe and therefore its placement within this section is questionable (see also Pringle, 1977).

In general, all species of Gentiana sect. Pneumonanthe bear small green rosette leaves at least in the seedling stage or as juvenile plants, but some individuals in a few species and in most specimens of $G$. cachemirica maintain small green foliage leaves in the adult stage as well. Smith (1961) speculated about close affinities between Gentiana cachemirica and the eastern Caucasian populations of G. septemfida. The latter species is extremely variable and includes several subspecies growing in rather different habitat types, including alpine and upper forest belt pastures, and rocky crevices from 500 up to $2400 \mathrm{~m}$ above sea level (Dolukhanov, 1948; Grossheim, 1952, 1967; Kolakovsky, 1978; Gagnidze, 1985; Davitashvili \& Karrer, 2006). Apparently the hypothesis of Smith (1961) was based on ecological and gross morphological data. Both Gentiana cachemirica and G. septemfida subsp. lagodechiana Kolak. grow on moist rocky ledges and are characterized by ovate leaves and fimbriate plicae (characters 6, 16 in Fig. 4A) and the present morphological and phylogenetic cluster analyses confirm his suggestion (Fig. 4).

\section{Distribution and ecology}

Distribution and ecological patterns can provide additional valuable information for plant taxonomy (Stuessy, 1990). The species of Gentiana sect. Kudoa and Gentiana sect. Isomeria, with the exception of G. glauca Pall., that extends to the Far East, Japan and North America, and G. yakushimensis Makino, an endemic species of Yakushima island, are restricted to the central and eastern parts of the Himalayas and the mountains of southeastern Asia (Toyokuni, 1960; Garg, 1987; Aitken, 1999; Ho \& Pringle, 1995; Ho \& Liu, 2001) (Fig. 5). Takhtajan (1986) includes this area in his 'Eastern Asiatic floristic region', characterized by heavy monsoon rainfalls that decrease rapidly in the western parts of the Himalayan chains (Bartholomew, 1988). Gentiana sect. Kudoa and Gentiana sect. Isomeria seem to have evolved along with the establishment of monsoon climates in southeastern Asia and are likely to be adapted to high amounts of summer precipitation, which are absent in the western Himalayas and the Hindu Kush mountains (Hadač, 1970; Meusel \& Schubert, 1971; Haserodt, 1989; Schikoff, 1994; Peer et al., 2001). This may be a reason why the floras of Pakistan and Kashmir lack any representatives of these sections. 


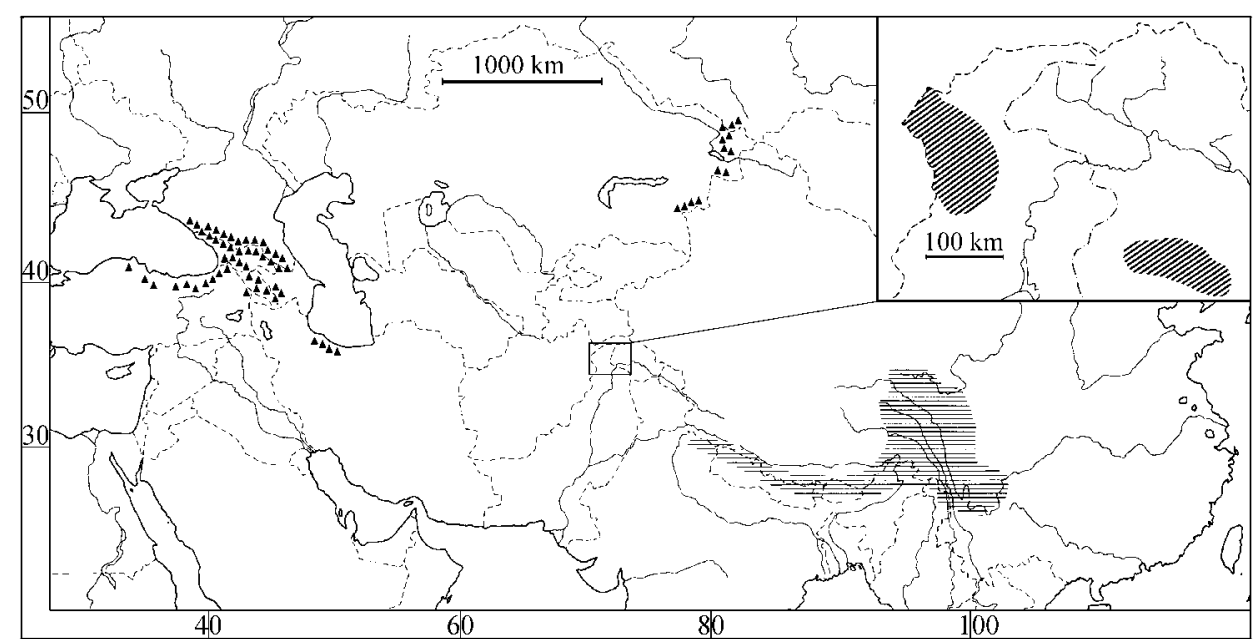

^ Gentiana septemfida

目 Gentiana sections Kudoa and Isomeria

Gentiana cachemirica

_ Rivers and shorelines _ --- Country borders

FIG. 5. Distribution of gentians in southwestern Asia.

Representatives of Gentiana sect. Pneumonanthe occur in Europe, Western Asia, Siberia, the Far East and North America between 0 and $2400 \mathrm{~m}$ a.s.l. and have not been recorded from the Central and Eastern Himalayas. Gentiana cachemirica does not grow in places of high monsoon rains, but occurs in the southern Hindu Kush and western Himalayas (Fig. 5). This species is confined to a small area belonging to the 'Irano-Turanian floristic region' where the humidity is optimal for its growth (Takhtajan, 1986). Gentiana septemfida appears quite near to the distributional range of G. cachemirica, in Caucasus, Elburz, Alatau and the Altai mountains. This scattered distribution of Gentiana septemfida and $G$. cachemirica suggests the possibility of a former continuous range of an ancestral species throughout Western and Central Asia (including Tien-Shan, Pamir, Hindu Kush, Elburz and Caucasus) during periods of more humid climate.

\section{ACKNOWLEDGEMENTS}

We are grateful to the curator and staff of E (especially Suzanne Cubey for sending the specimens of Gentiana cachemirica), David Goyder from K, Ernst Vitek from W, and David Kikodze from TBI. The illustrations were done by Norbert Frotzler. We also wish to express our thanks to Bernhard Dickoré, Thomas Denk, Chris Brickell and the anonymous reviewers. The study was supported by the ÖAD (Austrian Exchange Service). 


\section{REFERENCES}

Aitken, E. (1999). Family 160. Gentiana. In: Grierson, A. J. C. \& Long, D. G. (eds) Flora of Bhutan, vol. 2, pp. 633-656. Edinburgh: Royal Botanic Garden Edinburgh and Royal Government of Bhutan.

Bartholomew, J. C. (1988). The New York Times Atlas of the World. New York: Times Books.

Bouman, F., Сobb, L., Devente, N., Goethals, V. \& Maas, M. (2002). The seeds of Gentianaceae. In: Strume, L. \& Albert, V. A. (eds) Gentianaceae: Systematics and Natural History, pp. 498-572. Cambridge: Cambridge University Press.

Chen, S., Xia, T., Wang, Y., Liu, J. \& Chen, S. (2005). Molecular systematics and biogeography of Crawfurdia, Metagentiana and Tripterospermum (Gentianaceae) based on nuclear ribosomal and plastid DNA sequences. Ann. Bot. 96: 413-424.

Clarke, C. B. (1885). Gentiana. In: Hook er, J. D. (reprint 1984) (ed.) The Flora of British India, vol. 4, pp. 108-119. Delhi: Jayyed Press.

Davitashvili, N. \& Karrer, G. (2003). Gentiana scabra and Gentiana triflora are monopodial gentians. Palmarum Hortus Francofurtensis 7: 139.

Davitashvili, N. \& Karrer, G. (2006). Taxonomic relationships of the western Asian taxa of Gentiana sect. Pneumonanthe. Bot. J. Linn. Soc. 153(2): 197-208.

Doluk hanov, A. G. (1948). Zametki o Kavkazskikh gorechavkakh podsekzii Septemfidae Kusn. Zametki Sist. Geogr. Rast. 14: 38-60.

Fitch, W. M. (1971). Towards defining the course of evolution: minimum change for a specific tree topology. Syst. Zool. 20: 406-416.

Gagnidze, R. (1985). Gentiana L. In: Gagnidze, R. \& Kutateladze, Sch. (eds) Flora of Georgia, vol. 10, pp. 123-143. Tbilisi: Mecniereba.

Ga R G, S. (1987). Gentianaceae of the North West Himalaya. New Delhi: Today and Tomorrow's Printers and Publishers.

Greimler, J., Hermanowski, B. \& JAng, C-G. (2004). A re-evaluation of morphological characters in European Gentianella section Gentianella (Gentianaceae). Pl. Syst. Evol. 248: 143-169.

Grossheim, A. A. (1952). Gentiana. In: Shishin, B. K. \& Bobrov, E. G. (eds) Flora SSSR, vol. 18, pp. 538-620. Moskva-Leningrad: AN SSSR.

Grossheim, A. A. (1967). Gentiana. In: Grossheim, A. A. (ed.) Flora Kavkaza, vol. 7 , pp. 208-212. Leningrad: Nauka.

HADAč, E. (1970). A plant collection from Hindukush. Feddes Repert. 81(6-7): 457-479.

HAGEN, K. B. von \& KAdereit, J. W. (2003). The diversification of Halenia (Gentianaceae): ecological opportunity versus key innovation. Evolution 57: 2507-2518.

Halda, J. J. (1996). The genus Gentiana. Dobré: Sen. Vydav.

Haserodt, K. (1989). Chitral (pakistanischer Hindukusch): Strukturen, Wandel und Probleme eines Lebensraumes im Hochgebirge zwischen Gletschern und Wüste. In: Haserodt, K. (ed.) Hochgebirgsräume Nordpakistans im Hindukusch, Karakorum und Westhimalaya: Beiträge und Materialen zur Regionalen Geographie, pp. 44-180. Berlin: Institut für Geographie der Technischen Universität Berlin.

Ho, T.-N \& Pringle, J. S. (1995). Gentianaceae. In: W u, Z.-Y. \& Raven, P. H. (eds) Flora of China, vol. 16, pp. 1-139. Beijing, St Louis: Science Press, Missouri Botanical Garden Press.

Ho, T.-N \& Liu, S.-W. (1990). The infrageneric classification of Gentiana (Gentianaceae). Bull. Brit. Mus. (Nat. Hist.), Bot. 20: 169-192.

Ho, T.-N \& Liu, S.-W. (2001). A Worldwide Monograph of Gentiana. Beijing: Science Press. 
Jang, C.-G., Müllner, A. N. \& Greimler, J. (2005). Conflicting patterns of genetic and morphological variation in European Gentianella section Gentianella. Bot. J. Linn. Soc. 148: $175-187$.

KARRER, G. (1997). Growth form characters and growth strategies as a tool for taxonomy in Gentiana L. Scripta Bot. Belg. 15: 90.

Kolakovsky, A. A. (1978). New data on the taxonomy and origin of some Caucasian Gentiana. Bull. Acad. Sci. Georgian SSR 92(1): 161-164.

Kusnezow, N. I. (1894). Podrod Eugentiana Kusnez. roda Gentiana Tournefort: Sistematicheskaya, morfologicheskaya i geogreficheskaya obrabotka. St Petersburg: Dermakov.

Löve, A. \& Löve, D. (1972). Favargera and Gentianodes, two new genera of alpine Gentianaceae. Bot. Not. 125: 255-258.

Maddison, W. P. R. \& Maddison, D. R. (1992). MacClade, Version 3.0.1. Sunderland, MA: Sinauer Associates.

MészÁros, S. (1994). Evolutionary significance of xanthones in Gentianaceae: a reappraisal. Biochem. Syst. Ecol. 22(1): 85-94.

Meusel, H. \& Schubert, R. (1971). Contributions to the plant geography of the western Himalayas. Flora 160: 137-194.

Omer, S. \& Qaiser, M. (1995a). Seed morphological studies in the genus Gentiana L. (s.l.) (Gentianaceae) from Pakistan and Kashmir. Turkish J. Bot. 19(6): 581-593.

Omer, S. \& Qaiser, M. (1995b). Gentianaceae. In: Ali, S. I. \& Qaiser, M. (eds) Flora of Pakistan, vol. 197, pp. 1-172. Karachi: University of Karachi.

Peer, Th., Millinger, A., Grubner, J-P. \& Hussain, F. (2001). Vegetation and altitudinal zonation in relation to the impact of grazing in the steppe lands of the Hindu Kush Range (N-Pakistan). Phytocoenologia 31(4): 477-498.

Polunin, O. \& Stainton, A. (1990). Concise Flowers of the Himalaya. Oxford: Oxford University Press.

Pringle, J. S. (1977). Taxonomy and distribution of Gentiana (Gentianaceae) in Mexico and Central America. I. Sect. Pneumonanthe. Sida 7(2): 174-217.

Renobales, G., de Diego, E., López-Quintana, A. J. \& Domingues, J. B. (1999). Vegetative morphology in the genus Gentiana L. In: Kurman, M. H. \& Hemsley, A. R. (eds) The Evolution of Plant Architecture, pp. 123-133. Kew: Royal Botanic Gardens.

Schik off, U. (1994). Die Verbreitung der Vegetation im Kaghan-Tal (Westhimalaya, Pakistan) und ihre Kartographische Darstellung im Massstab 1:150 000. Erdkunde 48: 92-110.

Schiman-Czeik a, H. (1967). Gentiana. In: Rechinge R, K. H. (ed.) Flora Iranica, vol. 41, pp. 10-22. Graz: Akademische Druck u. Verlagsanstalt.

Serebryakova, T. I. (1979). Models of shoot formation and some evolutionary trends in the genus Gentiana L. Byull. Moskovsk. Obshch. Isp. Prir. Otd. Biol. 84(6): 97-109.

Sмiтн, H. (1961). Problems relating to the Gentiana cachemirica of the 'Flora of British India'. Kew Bull. 15: 43-55.

Strume, L. \& Albert, V. A. (2002). Gentianaceae: Systematics and Natural History. Cambridge: Cambridge University Press.

Stuessy, T. F. (1990). Plant Taxonomy: The Systematic Evaluation of Comparative Data. Columbia: Columbia University Press.

Swofford, D. L. (1998). PAUP*. Phylogenetic Analysis Using Parsimony (and other methods), Version 4. Sunderland, MA: Sinauer Associates.

Tak htajan, A. L. (1986). Floristic Regions of the World. Berkeley: University of California Press. 
Tоyок Uni, H. (1960). Über die systematische stellung von Gentiana yakushimensis. J. Jap. Bot. 35: 201-204.

YuAN, Y.-M. (1993). Seedcoat micromorphology and its systematic implications in Gentianaceae of Western China. Bot. Helvet. 103: 73-82.

Yuan, Y.-M., KüPfer, Ph. \& Doyle, J. J. (1996). Infrageneric phylogeny of the genus Gentiana (Gentianaceae) inferred from nucleotide sequences of the internal transcribed spacers (ITS) of nuclear ribosomal DNA. Amer. J. Bot. 83(5): 641-652.

Yuan, Y.-M., Wohlhauser, S., Möller, M., Klackenberg, J., Callmander, M. \& KÜPfER, PH. (2005). Phylogeny and biogeography of Exacum (Gentianaceae): A disjunctive distribution in the Indian Ocean basin resulted from long distance dispersal and extensive radiation. Syst. Biol. 54(1): 21-34.

Received 28 February 2007; accepted for publication 22 August 2007

\section{APPENDIX 1}

\section{Selected specimens examined}

Gentiana cachemirica. InDIA. Kashmir, N facing side of valley leading to Mt. Kolahoi's north glacier, on a small cliff in pockets of soil amongst the rock and hanging down, 8 viii 1983, Chadwell et al. 446 (E); Kashmir, $8000 \mathrm{ft}$, vi 1923, Douie 34 (K); in the Sind or Lidan valley? [probably Scindr valley common at Sonamany RRS], Radcliffe s.n. (K); Plants of N. W. Himalaya, Kashmir Amu, Lidden vy. 8500 ft, ix 1931, R. R. Stewart 12919 (K); W Himalaya, 14,000 ft, 14 viii 1999, J.F. Duthie 117 (K); Kashmir, near the Razbal Gali Pass above Lrishansar Lake, amongst rocks in crevices, 10 viii 1983, Chadwell et al. 441 (E); Kashmir, $11,000 \mathrm{ft}$, sub erect, growing on rocks, 26 viii 1924, B. O. Coventry 922 (K); Kashmir, Mt opp. Pahlgam, 10-11,000 ft, 28 viii 1945, R.R. Stewart 21795 (K); Kashmir, Sonamarg, rock crevices, 9000 ft, 19 viii 1922, R.R. Stewart 7348 (K); Kashmir, Sonamarg, rock crevices, rare, 9000 ft, 19 viii 1922, R.R. Stewart 7203 (K).

Pakistan. Chitral, x 1904, A. Barrett s.n. (K); Chitral, Lowani Pass, grassy slopes, Toppin 595 (K); Dir, Loher top, 5 x 1964, Salin s.n. (K); Hazara, Kagan Valley, 14,400ft, 22 viii 1996, J.F. Duthie 19955 (K); Hazara, in rock crevices on open hillsides, 17 ix 1958, B.L. Burtt \& M.A. Kazmi 1244 (E); Kupwara(?), Shönthar Valley, cliff faces, 19 viii 1935, F. Ludlow \& G. Sherriff 1515 (E); Swat, Batain above Ushu cliffs, $9000 \mathrm{ft}, 27$ vii 1953, R.R. Stewart \& A. Rahman 25312 (K).

Gentiana depressa. China. Tibet, Taliuig, $9000 \mathrm{ft}$; x [19]24, C.S. Cutting \& A.S. Vernay 128 (K). InDia. Sikkim, Alpine Sikkim, iii 1877, Comm. Elives s.n. (K); ibid., 15,000 ft, xi 1880, J.S. Gamble 9970 (K).

Nepal. Gossain Than, 1832, Wallich 4387 (K); Flora of Nepal, 12,600 ft, growing in full exposure on heavily grazed land occasionally at edge of thickets of rhododendron and cotoneaster, 12 x 1970, B. Halliwell 64 (K); Marsyandi valley, between Pisang and Chame, on grassy scree, $2900 \mathrm{~m}$ a.s.1., 29 x 1969, T. Wraber 519 (K); Taplejung, Ghunsa, $3300 \mathrm{~m}$ below Ghunsa on sandy river bank, rare in this area (only specimen seen), 24 ix 1985, Curzon 86 (K); Marpa fields, c.4000 m, 7 ix 1973, Grey-Wilson \& Phillips 799 (K).

Gentiana gelida. Armenia. Aragatson, Aparan distr., dry subalp. meadow with rocks, $2180 \mathrm{~m}$, 24 viii 2005, E. Vitek et al. 05-1883 (W); Shirak, Amasia distr., meadow with limestone rocks, 
31 viii 2005, E. Vitek et al. 05-2214 (W); at lake Arpilich, meadows and shore of lake, 31 viii 2005, E. Vitek et al. 05-2184 (W).

Georgia. Trialeti, surroundings of Manglisi, edge of oak forest, $1700 \mathrm{~m}, 31$ viii 2001, Davitashvili 01-10 (TBI); Algeti reserve, meadow in oak-pine forest, 2000 m, 20 viii 2003, Davitashvili 03-21 (TBI); Javakheti, grazed subalpine meadow at Tabatskuri lake, $2200 \mathrm{~m}$, 24 viii 2001, Davitashvili 01-07 (TBI).

Gentiana pneumonanthe. Austria. Nordtirol, Kreckelmoos bei Reutte, 930 m, 2 viii 1974, Seipka 088800 (W); Osttirol, Hohe Tauern, Schober Gruppe 9 km SW Defreggerhof, c.1220 m, Feuchtwiese, Quellmoore, 18 viii 1988, Frendl 015778 (W).

Czech Republic. Bohemia australis in pascuis ad septentriones versus a vico Jindřichovice, 500 m, 3 ix 1972, Deyl 344 (W).

Poland. Polonia centralis regio elata Montes, in prato solo sasulosi argilloso acido, 16 viii 1971, H. Piękos \& M. Ptak 371 (W).

Portugal. Minho, Esposende nospintialis, em terrenos múmidos, 9 ix 1964, Bento $V$. Raintia 6248 (W).

Russia. Moscow, Distr. Ramenskoe, prope Kratovo, in prato, 1 viii 1976, Proskuriakova 81 (W); Rjasan, distr. Solotcza, prope pag Dolginino, in prato humido turfoso, 8 viii 1969, Dovikov 5290 (W); Smolensk, near Gnezdilovo, wet places, 1 viii 1971, Mokarov 6381 (W).

SlovaKia. In pratis siccis prope vicum Skalica, 200 m, 20 vii 1929, Sellinger 343 (W).

Switzerland. In pratis humidis, 24 ix 1972, Dittrich 157 (W).

Gentiana scabra. ChinA. Kalkhügel in Kisngsu, 1933, Wissmann 7677 (W); Prov. Kwangtung, ad orientem urbis schnakwan, viii 1928, Fenzel 138 (W); W Hupeh, ix 1929, Fenzel 2666 (W); Kuling near Kiukiang, grassy ground on hill top, 29 ix 1929, H. Chung 4102 (W); Manchuria chinensis, fluvium Amur, viii 1905, F. Karo s.n. (W).

JAPAn. Mt. Kiyosumi, 30 x 1957, N. Maruyama 1616 (W); Nikko in Shimotsuko, 29 x 1953, H. Kubota 993 (W); Jokohama, Wawra 1516 (W); Moraba in Shimosa, 3 xi 1963, T. Koyana 833 (W); Jokohama, ix 1862, Maximovicz 130 (W).

Korea. Im herbidis, x 1906, Fauhiz 751 (W).

Russia. Primorsk, Inter Talolan et Siaololan, 11 ix 1927, Kozlow 14286 (W); Prov. propeurb. Voroschilov, in locus humidis, 23 ix 1905, Palczevskyi 3643 (W); Blagowjestschenk im Amurgebiete auf Anhöhen im Gebüsche, viii 1898, F. Karo 50 (W); Prov. Amur, Blogovesczensk in pratis silvaticus et substeposis, 4 ix 1904, F. Karo 3643 (W).

Gentiana septemfida. Armenia. Lori, Stepanavan distr., Pushkin pass, 2028 m, 4 ix 2005, E. Vitek et al. 05-2460 (W); Kotayk, Hrazdan distr., 5 km NW of Meghrazdos, 2455 m, 6 ix 2005, E. Vitek et al. 05-2586 (W); Shirak, Ashotsk distr., Karakhach pass, 2190 m, 1 ix 2005, E. Vitek et al. 05-2346 (W).

Georgia. Kartli, Bakuriani, Iagora meadow, wet places, 25 vii 2001, Davitashvili 01-01 (TBI); Tskhratskaro pass, subalpine meadow, 2400 m, 15 ix 1997, Davitashvili 97-12 (TBI); Kakheti, Lagodekhi reserve, clay rocks near waterfall, 800 m, 5 ix 2003, Davitashvili 03-25 (TBI); Lagodekhi reserve, on wet rocky crevices, 900 m, 7 ix 2003, Davitashvili 03-27 (TBI); Khevi, Sno valley, subalpine meadow, 2700 m, 10 viii 1993, Davitashvili 93-08 (TBI); Racha, Satsalike, meadow with limestone rocks, 2200 m, 9 viii 2001, Davitashvili 01-06 (TBI); Svaneti, grazed subalpine meadow near village Hadishi, 12 viii 1991, Davitashvili 91-04 (TBI); Samegrelo, Askhi Plateau, Chkhvindjula, limestone rocks, 2200 m, 25 viii 1997, Davitashvili 97-08 (TBI); Egrisi ridge, limestone crevices, 1700 m, 11 viii 1991, Davitashvili 91-03 (TBI).

Iran. Wiese bei der Karawanenstation Pelur, 1900 m, 28 viii 1936, A. Gilli 1885 (W); Elburz, Gomies Notkaraj, moist mossy sloping banks by a spring, 28 viii 1966, Southern Zagros Bot. Exp. A53 (W); Mazanderan, in declibus borealibus jugi Kandavan, 25 viii 1948, 
K.H. Rechinger 6742 (W); Distr. Nur, Kamorband, 2400-2600 m, K.H. Rechinger 6395 (W); Kandavan pass, alpine meadow, moist patches, 8 ix 1977, Breckle 5355 (W); Ostan, deuxversants du Gol du Kuruk, au dessus de Gach-i-sar, 16 viii 1956, F. Schmidt 6479 (W); Tehran: Karaj valley, Assemvarak steep wet slope, 25 viii 1874, P. Wendelbo 14479 (W).

Turkey. Trabson, mont. Kankanli Dağlari in vicinitate pylarum zigana, 2030-2400 m, 30 viii 1993, V. Vašák 09984 (W).

Gentiana stipitata. China. Sikang, between Taining (Ngata) and Taofu (Dawo) in duriprato aprico, c.3800 m, 10 ix 1934, H. Smith 12005 (K); Kangting (Tachienlu) distr., Cheto La, 4000-4200 m, 12 x 1934, H. Smith 12834 (K); Taofu (Dawo) distr., Kuku La, xii 1934, H. Smith 13913 (K); Taofu (Dawo) distr., Taining (Ngata) colles orient., in duriprato aprico, c.3700 m, 9 ix 1934, H. Smith 11970 (K); Szechuan, reg. bor-occid. Natang? alp. bor-occid. in prato aprico, c.3500 m, 17 ix 1922, H. Smith 4399 (K); Tibet: Tongolo (Principauté de Kiala), 1893, J.A. Soulié 2813 (K).

INDIA. Beautiful clumps at Noosoo Bassa, North side of Roofia Pap, 12,000 ft, Edgeworth 47 (K); Himalaya, c.13,000 ft, 1844, Edgeworth 82 (K); Flora of North Western India, ix 1983, Duthies 1186 (K); Tihri - Garhwal, Kidari Naula, near the summit, 7 x 1979, J.S. Gamble 1192 (K).

NePal. Midway between Jengla and Tarag, c.4700 m, 26 viii 1973, Grey-Wilson \& Phillips $743(\mathrm{~K})$.

Gentiana szechenyii. ChinA. Western China, 13,000 ft, 9 iii year unknown, E.H. Wilson 4145 (K); Szechuan, reg. bor.-occid. Tsipula in rupileus calcareis, c. $4700 \mathrm{~m}, 26$ viii 1922, H. Smith 4203 (K); reg. bor.-occid. Natang alp. austr-orient in rupibus, c. 4700 m, 13 ix 1922, H. Smith 4362 (K); on slopes of Ta-so Shen over 15,000 ft between Batang \& Kanze, 1923, Oeieira? s.n. (K); Kansu, lower Tebbu country, on clay \& conglomerate cliffs below Tsarekika, eastern Minshan, 10,000 ft, 18 ix 1926, J.F. Rock 14861 (K); Sikang, Kangting (Tachienlu) distr., Cheto La, in prato alpino ventoso, 4000-4200 m, 12 x 1934, H. Smith 12835 (K); Taofu (Dawo) distr., reg. orient., Lhamo Mondeh La, in prato alpino lapidoso, 4300-4500 m, 21 ix 1934, H. Smith 12358 (K); between Taining (Ngata) and Maoniu (Ndrömé), Zungkong La, Chinche Dento, in prato alpino, c.4000 m, 29 ix 1934, H. Smith 12539 (K).

InDiA. Yulong Shan, Gang Ho Ba Valley, 3200 m, valley floor in very open woodland in poor very fine soil, 4 x 1990, Chungtien-Lijiang-Dali Expedition CLD-90 No. 757 (K).

Gentiana urnula. Bhutan. Mo Chu, S slope of Yale La, $27^{\circ} 47^{\prime} \mathrm{N}, 89^{\circ} 27^{\prime} \mathrm{E}$, Dry unstable scree, Med. Ganga chung., c.4780 m, 3 x 1984, I. W.J. Sinclair \& D. G. Long 5504 (K).

China. Tibet, main Ronhbuk glacier, Moraine, 18,000 ft, 16 v 1938, Lloyd 21 (K); Atsa (Pass above monastery), F. Kingdon Ward 6149 (K); Mount Everest expedition, Rongbate valley on moraine not common also found on high ?, 17,000 ft, 26 v 1924, R.W.G. Hingston 379 (K); near Phari, 14,500 ft, ix 1938, B.J. Gould 1634 (K); Pass E. of Jira Valley, 28¹4' N, $85^{\circ} 51^{\prime} \mathrm{E}, 5380 \mathrm{~m}$, sparsely vegetated screes, 13 x 1987, C.M.A. Roberts 572 (K); Khambajong, ix 1903, D. Prain s.n. (K).

NePal. Sankwasabha, Barun Khola, Makalu base camp, high rocky mountain slopes, GreyWilson et al. 4302 (K); Mount Everest expedition, 17,000 ft, viii 1921, A.F.R. Wollaston 213 (K); Mount Everest expedition, 17,000-19,000 ft, ix 1921, A.F.R. Wollaston 214 (K); Mount Everest expedition, 17,000-19,000 ft, ix 1921, A.F.R. Wollaston 204 (K).

Gentiana veitchiorum. BhutAn. Bapekha, 14,000 ft, 14 viii 1938, B.J. Gould 1543A (K).

ChinA. Tibet, Pasum Lake, abundant on alpine turf slopes around Atsa?, 11,000-12,000 ft, 19 viii 1924, F. Kingdon Ward 6114 (K); Gyainda, in alpine pastures, 30 viii 1924, F. Kingdon Ward $6171(\mathrm{~K})$; Tsarong, open marshy moorland on the Salwin-Kiu Chiang divide, $28^{\circ} 24^{\prime} \mathrm{N}$, 982'ㄹ E, 14-14,500 ft, x 1921, G. Forrest 20875 (K). 


\section{Appendix 2}

Multistate character matrix used for the cluster analysis of Gentiana cachemirica and possible relatives

\begin{tabular}{lllllllllllllllllll}
\hline \hline Taxon & 1 & 2 & 3 & 4 & 5 & 6 & 7 & 8 & 9 & 10 & 11 & 12 & 13 & 14 & 15 & 16 & 17 \\
\hline G. acaulis & 0 & 1 & 0 & 1 & 1 & 1 & 0 & 1 & 0 & 0 & 1 & 1 & 0 & 0 & 1 & 0 & 0 \\
G. andrewsii & 1 & 0 & 1 & 1 & 0 & 1 & 1 & 1 & 1 & 1 & 1 & 1 & 3 & 3 & 0 & 2 & 1 \\
G. cachemirica & 1 & 0 & 1 & 0,1 & 1 & 0 & 1 & 1 & 1 & 1 & 1 & 1 & 1 & 1 & 0 & 2 & 1 \\
G. clusii & 0 & 1 & 0 & 1 & 1 & 1 & 0 & 1 & 0 & 0 & 1 & 1 & 0 & 0 & 1 & 0 & 0 \\
G. cruciata & 1 & 0 & 1 & 0 & 1 & 1 & 1 & 1 & 1 & 1 & 0 & 0 & 0 & 1 & 0 & 1 & 1 \\
G. depressa & 0 & 1 & 0 & 1 & 1 & 1 & 0 & 0 & 1 & 1 & 1 & 1 & 0 & 2 & 0 & 0 & 0 \\
G. gelida & 1 & 0 & 1 & 1 & 0 & 0 & 1 & 1 & 1 & 1 & 1 & 1 & 3 & 1 & 0 & 1 & 1 \\
G. olivieri & 1 & 0 & 1 & 0 & 1 & 1 & 1 & 1 & 1 & 1 & 0 & 0 & 0 & 1 & 0 & 1 & 1 \\
G. pneumonanthe & 1 & 0 & 1 & 1 & 0 & 1 & 1 & 1 & 1 & 1 & 1 & 1 & 1 & 1 & 1 & 1 & 1 \\
G. scabra & 1 & 0 & 1 & 1 & 0 & 1 & 1 & 1 & 1 & 1 & 1 & 1 & 2 & 1 & 1 & 1 & 1 \\
G. sceptrum & 1 & 0 & 1 & 1 & 0 & 1 & 1 & 1 & 1 & 1 & 1 & 1 & 1 & 1 & 1 & 1 & 1 \\
G. septemfida & 1 & 0 & 1 & 1 & 0,1 & 0 & 1 & 1 & 1 & 1 & 1 & 1 & 1 & 1 & 0 & 2 & 1 \\
G. stipitata & 1 & 1 & 1 & 1 & 1 & 1 & 0 & 0 & 1 & 1 & 1 & 1 & 0 & 0 & 0 & 0 & 0 \\
G. szechenyii & 1 & 1 & 1 & 1 & 1 & 1 & 0 & 0 & 1 & 1 & 1 & 1 & 0 & 0 & 0 & 0 & 0 \\
G. urnula & 0 & 1 & 0 & 1 & 1 & 2 & 0 & 0 & 1 & 1 & 1 & 1 & 0 & 0 & 0 & 0 & 0 \\
G. veitchiorum & 1 & 1 & 1 & 1 & 1 & 1 & 0 & 0 & 1 & 1 & 1 & 1 & 0 & 0 & 0 & 0 & 0 \\
\hline \hline
\end{tabular}

